\title{
PENINGKATAN KEMAMPUAN MEMAHAMI CERITA \\ DONGENG MELALUI METODE DISKUSI PADA SISWA KELAS V SD NEGERI 10 SANUR
}

\author{
Ni Luh Sukanadi dan Ida Ayu Made Wedaswari
}

Program Studi Pendidikan Bahasa dan Sastra Indonesia, Fakultas Keguruan dan Ilmu Pendidikan, Universitas Mahasarswati Denpasar

\begin{abstract}
Abstrak
The undertaking of this research was titled improving oh history comprehension achievement on the discussion method by the fifth grade students of SD Negeri 10 Sanur in academic year 2009/2010 that was background of the problems of the students low or poor on the history comprehension ability. Because, the research question of the present study was classificated of classroom action research (CAR) formulated as follow : what does the discussion method can be increase students ability by the fifth grade students SD Negeri 10 Sanur on academic year 2009/2010 on the history comprehension achievement?. The theoretical framework which is used in present study includes of a literature meaning, kind of prose, a history meaning, kind of history, the elements of history, feedback to students about history, and discussion method. This study was made using classroom action research with perfected or increased study practice so that be batter. The result of research showed that the discussion method can increased students ability on the history comprehension achievement. Because of, can showed from first test scores, final test cycle I, final test cycle II, and final test cycle III. Where, on precycle (first test) scores showed the subjects figure of 4,32 increased of $42,82 \%$, on cycle I became 6,17 , on cycle II of $19,12 \%$ became 7,35 , and back up be $24,76 \%$, on cycle III was 9,12 .
\end{abstract}

Keyword : The history comprehension achievement with a discussion method.

\section{PENDAHULUAN}

Bahasa sebagai alat komunikasi antara manusia mempunyai peranan penting. Dengan bahasa, baik lisan maupun bahasa tulis seseorang dapat menyampaikan pesan atau informasi kepada orang lain. Agar dapat menyampaikan pikiran, perasaan ataupun informasi, maka si pemakai bahasa harus mempunyai keterampilan di dalam menggunakan bahasa serta mampu menafsirkan makna yang terkandung dalam suatu bahasa. Hal tersebut dapat dilihat dari kemampuan ketrampilan berbahasa yang meliputi (1) keterampilan menulis, (2) keterampilan membaca, (3) keterampilan berbicara, dan (4) ketrampilan menyimak. Keempat keterampilan tersebut mempunyai hubungan yang erat antara satu dengan yang lainnya (Slametmulyana, 1960:34). 
Peningkatan mutu pengajaran sastra Indonesia memang tidak terlepas dari usaha untuk meningkatkan mutu apresiasi siswa terhadap sastra Indonesia. Untuk mencapai hal itu, maka dewasa ini sedang giat-giatnya dilakukan usaha meningkatkan apresiasi siswa terhadap kesusastraan lama, khususnya dongeng. Apabila dikaji lebih jauh mengapa pemahaman dongeng lebih ditekankan dibandingkan dengan bentuk kesusastraan lama yang lain. Hal ini tentu ada alasannya. Dalam kenyataan di masyarakat, kebiasaan orang tua mendongeng pada anak-anaknya sudah semakin memudar. Apalagi dengan ditayangkannya film-film kartun di televisi, sehingga perhatian anak terhadap dongeng terus memudar atau mungkin hilang. Memahami cerita dongeng merupakan salah satu cara untuk meningkatkan mutu apresiasi siswa terhadap sastra Indonesia dan sebagai upaya untuk melestarikan kesusastraan lama.

Kemampuan siswa dalam mengapresiasi dongeng dipengaruhi oleh berbagai faktor, yaitu faktor dari dalam maupun faktor dari luar siswa tersebut. Faktor dari dalam berupa ketekunan siswa dalam mempelajari dongeng. Sedangkan faktor dari luar dapat berupa usaha-usaha guru itu sendiri, apakah guru tersebut hanya menugaskan siswa untuk sekedar membaca dongeng saja, atau menugaskan siswa untuk membaca sekaligus memahami cerita dongeng tersebut. Untuk dapat memahami cerita dongeng, ada beberapa metode yang dapat digunakan oleh guru, salah satunya adalah metode diskusi.

Metode diskusi yaitu komunikasi seseorang berbicara satu dengan yang lain, saling berbagi gagasan dan pendapat (Arends, 1997:12). Metode diskusi merupakan suatu percakapan ilmiah oleh beberapa orang yang tergabung dalam satu kelompok, untuk saling bertukar pendapat tentang suatu masalah atau bersama-sama mencari pemecahan mendapatkan jawaban dan kebenaran atas suatu masalah (Beyer, 1991:23).

Manfaat dari penerapan metode diskusi, yaitu : (1) dapat menumbuhkan keterlibatan dan partisipasi siswa, (2) siswa dapat mempelajari keterampilan berkomunikasi dan proses berpikir, (3) siswa belajar menilai kemampuan dan peranan diri sendiri maupun orang lain, (4) siswa dapat bersosialisasi dengan baik dengan teman dan gurunya, (5) siswa dapat menyadari dan mampu merumuskan berbagai masalah yang dihadapi baik dari pengalaman sendiri maupun dari pelajaran sekolah, (6) siswa dapat menyadari akan suatu problem dan memformulasikannya dengan menggunakan informasi yang diperoleh dari bacaan atau ceramah, dan (7) memahami 
apa yang ada di dalam pemikiran siswa dan bagaimana memproses gagasan dan informasi yang diajarkan melalui komunikasi yang terjadi selama pembelajaran berlangsung baik antarsiswa maupun komunikasi guru dengan siswa. Sehingga diskusi menyediakan tatanan sosial di mana guru dapat membantu siswa menganalisis proses belajar mereka.

Berdasarkan hal di atas, penelitian ini memfokuskan kepada tindakan mengajar yang perlu dilakukan guru di sekolah dasar untuk meningkatkan kemampuan memahami cerita dongeng melalui metode diskusi pada siswa kelas V SD Negeri 10 Sanur, Kecamatan Denpasar Selatan, Kotamadya Denpasar Tahun Pelajaran 2009/2010.

Tujuan dari penelitian ini adalah (1) memupuk dan mengembangkan kecakapan berpikir dinamis, rasional dan praktis, (2) memupuk dan mengembangkan kecakapan berbahasa Indonesia lisan dan tulisan, dan (3) memperkenalkan metode diskusi sebagai salah satu upaya untuk meningkatkan kemampuan memahami cerita dongeng serta (4) memberikan sumbangan berupa buah pikiran kepada lembaga, guru dan siswa dalam usaha meningkatkan pembinaan pengajaran bahasa Indonesia.

\section{METODE PENELITIAN}

Dalam penelitian ini penulis menggunakan jenis penelitian tindakan kelas. Menurut Carr dan Kemmis (dalam IGAK Wardani, 2007:13), penelitian tindakan kelas ini menekankan pada penyempurnaan atau peningkatan praksis pembelajaran sehingga menjadi lebih baik. Selain itu menurut Santyasa (2008 : 28) karakterristik dari penelitian tindakan kelas yaitu kegiatan modifikasi praktis yang dilakukan secara kontinu, kemudian hasil yang diperoleh akan terus dievaluasi sejalan dengan situasi yang terus berjalan sehingga mencapai suatu tujuan yaitu perbaikan terhadap sistem pembelajaran sesuai dengan kenyataan agar diperoleh suatu peningkatan mutu pembelajaran.

Rancangan penelitian yang digunakan dalam penelitian tindakan kelas berdasarkan model yang dikemukakan oleh Kurt Lewin. Konsep pokok penelitian tindakan kelas Kurt Lewin ini terdiri atas 4 komponen, yaitu: (1) perencanaan (planning), (2) tindakan (action), (3) pengamatan dan penilaian (observing dan evaluation), dan (4) refleksi (reflecting). Subjek penelitian tindakan kelas ini adalah 
siswa kelas V SD Negeri 10 Sanur, Kecamatan Denpasar Selatan, Kotamadya Denpasar Tahun Pelajaran 2009/2010 yang berjumlah 28 orang, dengan perincian siswa laki-laki sebanyak 15 orang dan siswa perempuan sebanyak 13 orang. Objek tindakan kelas ini adalah peningkatan kemampuan memahami cerita dongeng melalui metode diskusi siswa kelas V SD Negeri 10 Sanur, Kecamatan Denpasar Selatan, Kotamadya Denpasar, Tahun Pelajaran 2009/2010.

Tes yang digunakan adalah tes esai yang berjumlah 5 butir soal. Tiap soal memiliki rentang nilai 1-20. Skor dapat dilihat pada Tabel 1 berikut ini.

Tabel 01. Pemberian Skor/Nilai Tes Siswa Kelas V SD Negeri 10 Sanur Kecamatan Denpasar Selatan Kotamadya Denpasar Tahun Pelajaran 2009/2010

\begin{tabular}{|c|l|c|}
\hline No & \multicolumn{1}{|c|}{ Kriteria yang Dinilai } & Skor/Nilai \\
\hline $\mathbf{( 1 )}$ & \multicolumn{1}{|c|}{$(\mathbf{1})$} & $\mathbf{1}$ \\
\hline 1 & Ketepatan menentukan tema dan amanat dongeng. & $1-20$ \\
\hline 2 & $\begin{array}{l}\text { Ketepatan menentukan penokohan (perwatakan) dan latar } \\
\text { (setting) dongeng. }\end{array}$ & $1-20$ \\
\hline 3 & $\begin{array}{l}\text { Ketepatan menentukan sudut pandang dongeng dan kapan } \\
\text { dongeng dikarang. }\end{array}$ & $1-20$ \\
\hline 4 & $\begin{array}{l}\text { Ketepatan menentukan plot dan gaya bahasa dongeng. } \\
\text { masyarakat dalam dongeng. }\end{array}$ & $1-20$ \\
\hline 5 & $\begin{array}{l}\text { Ketepatan menentukan tujuan dongeng dan kepercayaan } \\
\mathbf{1 0 0}\end{array}$ \\
\hline
\end{tabular}

Dengan demikian skor/nilai yang ada pada masing-masing unsur tersebut, maka SMI dapat dicapai dengan :

$$
\mathrm{SMI}=5 \times 20=100
$$

\section{Membuat Pedoman Konversi Mengubah Skor Mentah Menjadi Skor Standar}

Membuat pedoman konversi untuk mengubah skor mentah menjadi skor standar, dengan norma absolut skala sebelas yakni berdasarkan pada tingkat penguasaan bahan yang diberikan (Nurkancana, $1986: 80$ ).

Adapun pedoman konversi skala sebelas sebagai berikut : 
Tabel 02. Pedoman Konversi Norma Absolut Skala Sebelas

\begin{tabular}{|c|c|c|}
\hline No & Tingkat Penguasaan & Skor Standar \\
\hline $\mathbf{( 1 )}$ & $\mathbf{( 2 )}$ & $\mathbf{( 3 )}$ \\
\hline 1 & $95 \%-100 \%$ & 9 \\
\hline 2 & $85 \%-94 \%$ & 8 \\
\hline 3 & $75 \%-84 \%$ & 7 \\
\hline 4 & $65 \%-74 \%$ & 6 \\
\hline 5 & $55 \%-64 \%$ & 4 \\
\hline 6 & $45 \%-54 \%$ & 3 \\
\hline 7 & $35 \%-44 \%$ & 2 \\
\hline 8 & $25 \%-34 \%$ & 1 \\
\hline 9 & $15 \%-24 \%$ & 0 \\
\hline 10 & $5 \%-14 \%$ & 5 \\
\hline 11 & $0 \%-4 \%$ & 10 \\
\hline
\end{tabular}

(Nurkancana, $1986: 84)$.

Berdasarkan Skor Maksimal Ideal (SMI) yaitu 100, maka dapat dihitung besar tiap-tiap proses penguasaan seperti di bawah ini :

Penguasaan $95 \%=95 / 100 \times 100=95$

Penguasaan $85 \%=85 / 100 \times 100=85$

Penguasaan $75 \%=75 / 100 \times 100=75$

Penguasaan $65 \%=65 / 100 \times 100=65$

Penguasaan $55 \%=55 / 100 \times 100=55$

Penguasaan $45 \%=45 / 100 \times 100=45$

Penguasaan $35 \%=35 / 100 \times 100=35$

Penguasaan $25 \%=25 / 100 \times 100=25$ 
Penguasaan $15 \%=15 / 100 \times 100=15$

Penguasaan $0 \%=0 / 100 \times 100=0$

Berdasarkan perhitungan di atas, maka pedoman konversi dapat diperhatikan dalam tabel berikut ini :

Tabel 03. Pedoman Konversi

\begin{tabular}{|c|c|c|}
\hline No & Tingkat Penguasaan & Skor Standar \\
\hline $\mathbf{( 1 )}$ & $\mathbf{( 2 )}$ & $\mathbf{3})$ \\
\hline 1 & $95-100$ & 9 \\
\hline 2 & $85-94$ & 8 \\
\hline 3 & $75-84$ & 7 \\
\hline 4 & $65-74$ & 6 \\
\hline 5 & $55-64$ & 5 \\
\hline 6 & $45-54$ & 4 \\
\hline 7 & $35-44$ & 2 \\
\hline 8 & $25-34$ & 1 \\
\hline 9 & $15-24$ & 0 \\
\hline 10 & $5-14$ & \\
\hline 11 & $0-4$ & 2 \\
\hline
\end{tabular}

(Nurkancana, 1986 : 98).

Berdasarkan tabel konversi di atas, maka ditentukan skor standar dari masingmasing siswa, yaitu yang mendapatkan skor mentah 95 - 100 akan memperoleh skor standar 10. Siswa yang mendapat skor mentah 85 - 94 akan memperoleh skor standar 9, yang mendapat skor mentah $75-84$ akan memperoleh skor standar 8. Demikian selanjutnya sampai siswa mendapat skor mentah $0-4$ akan memperoleh skor standar 0.

Tabel 04. Predikat Nilai Standar

\begin{tabular}{|c|c|}
\hline Nilai Standar & Predikat \\
\hline$(1)$ & $(2)$ \\
\hline
\end{tabular}




\begin{tabular}{|c|c|}
\hline 10 & Istimewa \\
\hline 9 & Baik sekali \\
\hline 8 & Baik \\
\hline 7 & Lebih dari cukup \\
\hline 6 & Cukup \\
\hline 5 & Hampir cukup \\
\hline 4 & Kurang \\
\hline 3 & Burang sekali \\
\hline 2 & Buruk sekali \\
\hline 1 & Gagal \\
\hline 0 & \\
\hline
\end{tabular}

(Nurkancana, $1986: 100)$.

\section{Menentukan Nilai Rata-rata (Mean)}

Untuk mengetahui kemampuan memahami cerita dongeng melalui metode diskusi pada siswa kelas V SD Negeri 10 Sanur, Kecamatan Denpasar Selatan, Kabupaten Denpasar dapat dicari nilai rata-rata yang diperolehnya.

Rata-rata $=\underline{\text { Jumlah Skor Standar }}$

Jumlah Siswa

(Partiani, 2009:73)

\section{HASIL PENELITIAN}

Berdasarkan penelitian yang dilakukan peneliti diketahui bahwa : (1) refleksi awal, pada kegiatan ini peneliti menilai kemampuan siswa dalam memahami dongeng melalui tes dan tahap ini tidak didahului dengan pemberian penjelasan. Pada refleksi awal ini diperoleh nilai rata-rata siswa sebesar 4,32. Berdasarkan pengamatan awal dalam pembelajaran menganalisis unsur-unsur pembangun dongeng, siswa kurang tertarik dalam mengikuti pembelajaran menganalisis unsur-unsur pembangun dongeng. Untuk itu peneliti mencoba alternatif baru yaitu dengan menggunakan metode diskusi. (2) Siklus 1 dilakukan dengan 4 langkah yaitu, (a) rancangan penelitian, pada tahap ini peneliti melakukan analisis kurikulum untuk mengetahui 
standar kompetensi dan kompetensi dasarnya, kemudian mempersiapkan RPP, serta mempersiapkan media yang mendukung dalam menerapkan metode diskusi, (b) pelaksanaan penelitian, pelaksanaan pembelajaran pada siklus 1 dilakukan dalam 2 kali pertemuan serta pada tahap ini peneliti menjelaskan mengenai hal-hal yang berkaitan dengan dongeng sesuai dengan RPP yang telah dibuat dan menggunakan metode diskusi, (c) observasi dan evaluasi, selama proses pembelajaran berlangsung, hasil observasi yang diperoleh adalah tidak semua siswa mengikuti pelajaran dengan tekun. Sebagian besar siswa terlihat pasif dalam mengikuti kegiatan diskusi, itu disebabkan karena siswa belum memahami prinsip-prinsip berdiskusi yaitu bekerja sama dalam memecahkan permasalahan. Evaluasi yang diberikan oleh guru dengan memberikan soal berbentuk esai yang terdiri dari 5 pertanyaan, (d) refleksi, dari hasil evaluasi diketahui rata-rata nilai yang dimiliki siswa sebesar 6, 17. Hal ini telah mengalami peningkatan dari tes awal yang telah dilakukan, tetapi belum mencapai kategori baik yang ditentukan peneliti.

Untuk itu penelitian dilanjutkan ke siklus II. Proses tindakan pada siklus II merupakan lanjutan dari tindakan siklus I. Hasil refleksi siklus I diperbaiki pada tindakan siklus II. Pelaksanaan siklus II dilaksanakan dengan 4 langkah yaitu, (a) rancangan penelitian, pada tahap ini peneliti mempersiapkan RPP, media yang mendukung dalam menerapkan metode diskusi, dan juga mempersiapkan tes akhir siklus II, (b) pelaksanaan penelitian, pelaksanaan pembelajaran pada siklus II dilakukan dalam dua kali pertemuan. Tahap ini peneliti membangkitkan pengetahuan siswa mengenai dongeng, selanjutnya memberikan pelajaran sesuai dengan RPP yang telah dibuat dan menggunakan metode diskusi, memberikan siswa sebuah dongeng untuk didiskusian, (c) observasi dan evaluasi, selama proses pembelajaran berlangsung, hasil observasi yang diperoleh adalah semua siswa mengikuti pelajaran dengan tekun tetapi ada beberapa siswa terlihat pasif dalam melaksanakan kegiatan diskusi karena belum memahami prinsip-prinsip berdiskusi yaitu bekerja sama dalam memecahkan permasalahan. Peneliti membagikan sebuah cerita dongeng dan memberikan 5 butir soal dalam bentuk esai dengan rentang skor antara 1-20 pada masing-masing siswa yang berhubungan dengan unsur-unsur pembangun dongeng, (d) refleksi, berdasarkan hasil tes akhir siklus II pada siswa kelas V SD Negeri 10 Sanur, Kecamatan Denpasar Selatan, Kotamadya Denpasar dapat diketahui bahwa nilai rata-rata siswa 7,35 dengan kategori lebih dari cukup. Hasil tes tersebut belum 
memenuhi target ketuntasan yang diharapkan yaitu 8,00 dengan katagori baik. Belum maksimalnya hasil tes kemampuan memahami cerita dongeng melalui metode diskusi disebabkan siswa belum sepenuhnya paham dalam menjawab pertanyaan. Masalah yang dihadapi siswa dalam memahami cerita dongeng yaitu kurangnya konsentrasi siswa dalam membaca dongeng yang diberikan sehingga tidak dapat menjawab pertanyaan dengan baik. Beberapa siswa terlihat pasif dalam melaksanakan kegiatan diskusi karena belum memahami prinsipp-prinsip berdiskusi yaitu bekerja sama dalam memecahkan permasalahan.

Untuk itulah penelitian ini dilanjutkan ke siklus III. Siklus ini dilakukan dalam 4 langkah yaitu, (a) rancangan penelitian, pada tahap ini peneliti mempersiapkan RPP, serta mempersiapkan media yang mendukung dalam menerapkan metode diskusi, dan juga mempersiapkan tes akhir siklus III, (b) pelaksanaan penelitian, pelaksanaan pembelajaran pada siklus III dilakukan dalam 2 kali pertemuan, pada tahap ini peneliti membangkitkan pengetahuan siswa mengenai dongeng, selanjutnya memberikan pelajaran sesuai dengan RPP yang telah dibuat dan menggunakan metode diskusi, memberikan siswa sebuah dongeng untuk didiskusikan berkelompok, (c) observasi dan evaluasi, selama proses pembelajaran berlangsung, hasil observasi yang diperoleh adalah semua siswa mengikuti proses pembelajaran dengan tekun, siswa bersemangat dalam mengikuti pembelajaran, dan siswa sangat aktif dalam melaksanakan kegiatan diskusi untuk memecahkan permasalahan yang diberikan peneliti yaitu untuk mencari unsur-unsur pembangun dongeng. Pelaksanaan evaluasi juga dilakukan dengan memberikan 5 soal esai kepada msing-masing siswa untuk mengetahui pemahaman mereka tentang dongeng, (d) refleksi, nilai rata-rata siswa dari tindakan siklus II ke tindakan siklus III mengalami peningkatan. Apabila dilihat secara nilai individu, semua siswa memenuhi target ketuntasan yang diharapkan yaitu 8,00 dengan katagori cukup. Pemahaman siswa dalam memahami cerita dongeng melaui metode diskusi sudah mengalami peningkatan.

Dari hasil yang diperoleh pada tindakan siklus III, dapat diketahui bahwa dengan penerapan metode diskusi dalam meningkatkan kemampuan memahami cerita dongeng pada siswa kelas V SD Negeri 10 Sanur, sudah dapat dikatakan efektif, karena dalam proses pembelajaran tersebut aktivitas belajar siswa secara keseluruhan sudah tampak lebih baik. Berdasarkan hasil yang dicapai dari pelaksanaan siklus III, 
maka peneliti tidak perlu melanjutkan pelaksanaan pembelajaran memahami cerita dongeng ke siklus berikutnya.

\section{PENUTUP}

Metode diskusi merupakan salah satu metode yang terbukti efektif dan dapat digunakan untuk meningkatkan pemahaman siswa dalam memahami cerita dongeng, serta merupakan salah satu metode yang dapat digunakan untuk membimbing siswa dalam memahami cerita dongeng, yaitu menemukan unsur-unsur pembangun dongeng. Hasil yang dicapai seperti di bawah ini.

Pada tes awal siswa memperoleh rata-rata 4,32, dengan rincian skor standar 3 dengan katagori kurang sekali sebanyak 5 orang, siswa yang memperoleh skor standar 4 dengan katagori kurang sebanyak 11 orang, siswa yang memperoleh skor standar 5 dengan katagori hampir cukup dan siswa yang memperoleh skor standar 6 dengan katagori cukup sebanyak 12 orang, sehingga kemampuan memahami cerita dongeng siswa pada tes awal dapat dikelompokkan dengan katagori kurang.

Tes akhir siklus I siswa memperoleh rata-rata 6,17, dengan rincian skor standar 7 dengan katagori lebih dari cukup sebanyak 11 orang, siswa yang memperoleh skor standar 6 dengan katagori cukup sebanyak 11 orang, dan siswa yang memperoleh skor standar 5 dengan katagori hampir cukup sebanyak 6 orang. Dari hasil tes awal ke siklus I sudah mengalami peningkatan tetapi hasil tes tersebut memenuhi target ketuntasan yang diharapkan yaitu 8,00 dengan katagori baik, sehingga penelitian dilanjutkan ke siklus II.

Pada tes akhir siklus II siswa memperoleh rata-rata 7,35, dengan rincian skor standar 6 dengan katagori cukup sebanyak 2 orang, siswa yang memperoleh skor standar 7 dengan katagori lebih dari cukup sebanyak 16 orang, siswa yang memperoleh skor standar 8 dengan katagori baik sebanyak 8 orang, dan siswa yang memperoleh skor standar 9 dengan katagori baik sekali sebanyak 2 orang. Nilai ratarata siswa dari tindakan siklus I ke tindakan siklus II mengalami peningkatan yang baik, tetapi hasil tes tersebut memenuhi target ketuntasan yang diharapkan yaitu 8,00 dengan katagori baik, sehingga penelitian dilanjutkan ke siklus III. 
Pada tes akhir siklus III siswa memperoleh rata-rata 9,17, dengan rincian skor standar 8 dengan kategori baik sebanyak 5 orang, siswa yang memperoleh skor standar 9 dengan kategori baik sekali sebanyak 13 orang, dan siswa yang memperoleh nilai 10 dengan kategori istimewa sebanyak 10 orang. Nilai rata-rata siswa dari tindakan siklus II ke tindakan siklus III mengalami peningkatan yang baik sekali. Apabila dilihat secara nilai individu, semua siswa memperoleh skor standar 8 ke atas. Berdasarkan hasil yang dicapai dari pelaksanaan siklus III, maka penelitian dihentikan sampai siklus III.

Peningkatan yang dicapai siswa dari tes awal, tes akhir siklus I, tes akhir siklus II, dan tes akhir siklus III sebagai berikut. Nilai rata-rata pada tes awal 4,32 dengan kategori kurang, mengalami peningkatan $42,82 \%$ menjadi 6,17 pada tes akhir siklus I dengan katagori cukup, pada siklus II meningkat 19,12\% menjadi 7,35 dengan katagori lebih dari cukup, dan kembali meningkat 24,76\% menjadi 9,17 pada tes akhir siklus III dengan katagori baik sekali.

Beberapa saran yang dikemukakan sehubungan dengan hasil yang diperoleh dalam penelitian ini adalah (1) dengan diketahuinya penerapan metode diskusi dapat meningkatkan kemampuan siswa dalam memahami cerita dongeng berhasil, maka pengajar hendaknya memanfaatkan metode diskusi dalam menerapkan pembelajaran di kelas, (2) pemberian kesempatan untuk melakukan diskusi dan bimbingan baik secara individu maupun kelompok, perlu ditingkatkan dan diintensifkan pelaksanaannya oleh para guru karena hal ini sangat penting untuk meningkatkan kemampuan memahami cerita dongeng, (3) dalam penerapan metode diskusi hendaknya pengajar mengawasi dan sekaligus mengoreksi siswa dalam berkegiatan, (4) siswa hendaknya membiasakan diri untuk membaca dongeng dan melatih diri mencari unsur-unsur pembangun dongeng sesering mungkin, sehingga hal tersebut dapat meningkatkan kemampuan siswa dalam memahami cerita dongeng, (5) siswa hendaknya lebih aktif dan kreatif dalam menerima pembelajaran, sehingga kegiatan pembelajaran dapat berlangsung dengan baik, (6) guru diharapkan dapat memberikan motivasi dan merangsang minat baca siswa, sehingga pengetahuan siswa tentang karya sastra, khususnya dongeng bertambah. 


\section{DAFTAR PUSTAKA}

Arends, RichardI. 1997. Classroom Instructional Management. New York: The McGraw-Hill Company.

Beyer, B. K.1991. Teaching Thinking Skills: A Handbook for Secondary School Teachers. Boston: Allyn and Bacon.

Hartoko, Dick dan B. Rahmanto. 1986. Pemandu di Dunia Sastra. Yogyakarta: Kanisius.

Hasibuan, J. J. dan Moedjiono. 1991. Proses Belajar Mengajar. Bandung: Remaja Rosdakarya.

Nurgiyantoro, Burhan. 1995. Teori Pengkajian Fiksi. Yogyakarta: Gajah Mada University Press.

Nurkencana, Suartana. 1986. Evaluasi Pendidikan. Surabaya: Usaha Nasional.

Partiani. 2007. Peningkatan Kemampuan Memahami Isi Bacaan dengan Menggunakan Teknik Pertanyaan pada Siswa Kelas VII SMPN 4 Amlapura Tahun Pelajaran 2006/2007. Denpasar : Universitas Mahasaraswati Denpasar.

Santyasa, I Wayan. 2008. Metode Penelitian Tindakan Kelas, Pengembangan Korelasional Kasual Komparatif dan Eksperimen. Singaraja: Undiksha.

Simandjuntak, B. Simorangkir. 1970. Kesusastraan Indonesia II. Jakarta: PT Pembangunan.

Todorof. 1985. Teori Pengkajian Fiksi. Yogyakarta: Adi Cita Karya Nusa.

Wardani,dkk. 2007. Penelitian Tindakan Kelas. Jakarta: Universitas Terbuka.

Zainuddin. 1992. Materi Pokok Bahasa dan Sastra Indonesia. Jakarta: Rineka Cipta. 